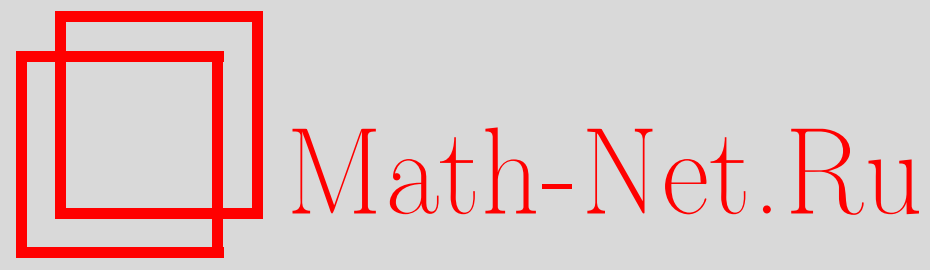

Медаль Фаддеева, Функи. анализ и его прил., 2016, том 50, выпуск 4, 1

DOI: https://doi.org/10.4213/faa3262

Использование Общероссийского математического портала Math-Net.Ru подразумевает, что вы прочитали и согласны с пользовательским соглашением http://www.mathnet.ru/rus/agreement

Параметры загрузки:

IP: 35.173 .219 .12

26 апреля 2023 г., 14:46:35

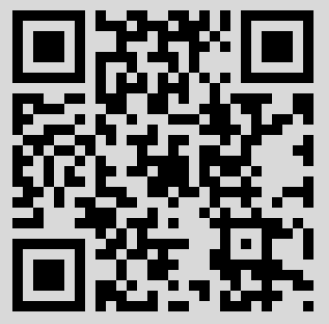




\section{Медаль Фаддеева}

Редакционная коллегия журнала «Функциональный анализ и его приложения» горячо поздравляет своего главного редактора Л. Д. Фаддеева с учреждением международной научной награды его имени.

Медаль Фаддеева учреждена Европейским исследовательским комитетом по квантовой проблеме нескольких частиц и тематической группой «Системы нескольких частиц» Американского физического общества. Она будет вручаться за выдающиеся достижения в физике нескольких частиц и является признанием основополагающего значения работы Людвига Дмитриевича для этого направления науки. 